\title{
THE EFFECT OF ALCOHOL ON THE WATER AND ELECTROLYTE BALANCE IN MAN
}

\author{
By WILLIAM M. NICHOLSON AND HAYWOOD M. TAYLOR \\ (From the Departments of Medicine and Biochemistry, Duke University School of \\ Medicine, Durham)
}

(Received for publication December 30, 1937)

The work presented here was undertaken primarily for the purpose of ascertaining the effect of alcohol in moderate quantities on the water and salt balance in man. It is a commonly observed fact that alcohol in man produces a diuresis and MacNider and Donnelly (1) have shown this to be the case in dogs. It is likewise well known that thirst is a prominent symptom during the recovery phase of acute alcoholism. No balance studies have been made of this condition, and it was thought that data could be collected which would explain some of the features observed.

Alterations in the acid-base balance after the ingestion of alcohol was first shown by Thomas (2) in 1898, who reported that the carbon dioxide content and carbon dioxide capacity of the blood was diminished. Himwich and coworkers (3) in 1933, made observations on the acid-base balance in dogs and in man after feeding alcohol. Their studies were made over short periods of time, and no attempt was made to study the electrolyte balance; however, they observed no change in the total base or chlorides of the serum. They found that there was a reduction in the carbon dioxide content and carbon dioxide capacity of the blood which was accompanied by a fall in the blood $\mathrm{pH}$. There was also an increase in the blood lactic acid and sugar. It was their belief that the increase in lactic acid was brought about by the conversion of muscle glycogen to lactic acid by the action of alcohol. Futer and coworkers (4) in short experiments on dogs noted a fall in the carbon dioxide capacity, an increase in the blood sugar, and an increase in the blood potassium content. Gojcher and coworkers (5) reported the same findings in chronic alcoholism in man, but made no attempt to study the excretion of the electrolytes.

Wakai (6) using rabbits, was able to show that the serum protein concentration was decreased and was accompanied by a decrease in the serum and blood viscosity after the feeding of alcohol. Levin (7) has shown that in man the ingestion of alcohol caused an increase in blood volume in certain instances.

\section{EXPERIMENTAL}

Healthy, young, adult male volunteers were used in the experiments. They were allowed to carry on their usual routine as students. A constant diet, which was prepared by the same individual throughout each experiment, was given. Two duplicate samples of the diet were analyzed for the potassium, sodium, chloride, water, and nitrogen content. The time at which fluid was taken and the amount were constant for each day throughout the experiment. A weighed amount of sodium chloride was supplied to the subject for use on his food for the day, and all food was consumed.

In order to determine the changes that might occur in periods shorter than 24 hours, the day was divided into three 8-hour periods. The urine was collected for each of the 8-hour periods, toluene added as a preservative, and the specimens were kept in the ice box until used. The stools were collected for 24-hour periods. The blood samples were collected anaerobically, heparin being used as the anticoagulant (8). A control blood was obtained 8 hours before the beginning of alcohol intake. The subject was given alcohol in the form of whiskey, gin or ethyl alcohol over a period of 8 hours, when a second blood sample was obtained. The third and fourth blood samples were obtained 8 and 32 hours respectively after the end of the alcohol consumption. The time at which fluid was taken remained the same in all experiments, alcohol being substituted for an equal quantity of water. No alcohol was allowed during the last hour of the period of alcohol intake, and the subject was kept at rest in bed. Vomiting did not occur in any of the experiments. In Experiments 1, 2, and 3 the subjects received alcohol in the form of whiskey, diluted with ice and water. In Experiment 5, the alcohol was given in the form of distilled gin diluted with water and ice, while in the 4th experiment ethyl alcohol diluted with ice and water was drunk. In two experiments ( 1 and 3) a low sodium chloride intake diet was given, 4 grams per day in Experiment 1, and 1 gram per day in Experiment 3, and in Experiments 2, 4, and 5 an adequate sodium chloride intake was allowed ( 7 grams per day).

The columns headed "balance" in Table IV represent the difference between the output and intake of the various substances, the output in each instance representing the total as measured by analyses of the urine, 
stools, and withdrawn blood. The intake represents the total amounts in the water, food, and sodium chloride taken by mouth. Periods labeled 1,2, and 3 are averages for the corresponding periods for two days and constitute controls. Period 4 represents the time of alcohol intake and during Periods 5 and 6 , it was considered that the subject was still under the influence of alcohol. The recovery phase begins with Period 7.

The methods for chemical analysis are as follows. Estimations of the sodium were made by the method of Butler and Tuthill (9). A trichloracetic acid filtrate of the plasma was used instead of wet or dry ashing. The filtrate was prepared in the manner recommended by Kerr (10). The potassium was estimated by the method of Shohl and Bennett (11), after ashing the sample according to the technique of Strauss (12). The chlorides were determined by the open Carius method as modified by Eisenman (13). The carbon dioxide content was measured by the method of Van Slyke and Neill (13). The $\mathrm{pH}$ determinations were made colorimetrically by the Hastings and Sendroy technique (14). Lactic acid estimations were made according to von Fürth-Charnass as modified by Friedemann and Kendall (13). The blood alcohol was determined by the method of Friedemann and Klaas (15). The macro-Kjeldahl method was employed for the determination of the nitrogen, in the plasma, urine, and stools (13). Nonprotein nitrogen was determined according to Folin and $\mathrm{Wu}$ (13) and the blood sugar by Benedict's method (13). All determinations were made in duplicate; unusual results were checked in triplicate.

\section{RESULTS}

Five complete balance studies were made, the results of which were consistent regardless of the form in which alcohol was taken. Data from such experiments (Tables I, II, and III) reveal that there was a retention of sodium, chloride, and potassium. A small amount of water was lost during the 24-hour period, but this loss was more striking during the 8-hour period in which the alcohol was given. Diuresis was produced and occurred always in the first 4 hours of the period, so that during the last 4 hours only small amounts of urine were voided, even though alcohol was taken during this time. Although there was a diuresis of water, the sodium, chloride, and potassium ions were retained and their concentration in the urine was lowered. Accompanying the water diuresis, which occurred only while the subject was taking alcohol, there was a loss of weight greater than could be accounted for by the loss of water in the urine alone.

The retention of the sodium and the chloride was more marked when the intake of these ions was high, and in the two experiments in which the sodium chloride intake was inadequate there was a negative balance for these ions, which, however, was not as great as in the control period (Table IV). In all experiments, the potassium retention (Table V) was marked and apparently had no relationship to the amount of sodium or chloride retained.

We have considered the recovery day as beginning 16 hours after the end of the period of

TABLE I

Effect of alcohol when adequate sodium chloride was given. Experiment $5 \dagger$

\begin{tabular}{|c|c|c|c|c|c|c|c|c|c|c|c|c|c|c|c|}
\hline Period & Weight & $\begin{array}{l}\text { Water } \\
\text { excre- } \\
\text { tion * }\end{array}$ & $\begin{array}{c}\text { Sodium } \\
\text { excre- } \\
\text { tion } *\end{array}$ & $\begin{array}{l}\text { Chlo- } \\
\text { ride } \\
\text { excre- } \\
\text { tion * }\end{array}$ & $\begin{array}{l}\text { Potas- } \\
\text { sium } \\
\text { excre- } \\
\text { tion * }\end{array}$ & $\begin{array}{l}\mathrm{pH} \text { of } \\
\text { blood }\end{array}$ & $\begin{array}{c}\text { Blood } \\
\text { non- } \\
\text { protein } \\
\text { nitro- } \\
\text { gen }\end{array}$ & $\begin{array}{l}\text { Blood } \\
\text { sugar }\end{array}$ & $\begin{array}{l}\text { Blood } \\
\text { lactic } \\
\text { acid }\end{array}$ & $\begin{array}{l}\text { Blood } \\
\text { alco- } \\
\text { hol }\end{array}$ & $\begin{array}{c}\text { Plasma } \\
\text { chlo- } \\
\text { ride }\end{array}$ & $\begin{array}{c}\text { Plasma } \\
80- \\
\text { dium }\end{array}$ & $\begin{array}{l}\text { Plasma } \\
\text { potas- } \\
\text { sium }\end{array}$ & $\begin{array}{c}\text { Plasma } \\
\mathrm{CO}_{2} \\
\text { content }\end{array}$ & $\begin{array}{c}\text { Plasma } \\
\text { pro- } \\
\text { tein }\end{array}$ \\
\hline $\begin{array}{r}8 \text { hours each } \\
\text { Control } \begin{array}{r}1 \\
2 \\
3\end{array}\end{array}$ & $\begin{array}{l}\text { kgm. } \\
71.4\end{array}$ & $\begin{array}{r}c c . \\
1000 \\
760 \\
1010\end{array}$ & $\begin{array}{l}m . e q . \\
40.8 \\
48.4 \\
43.5\end{array}$ & $\begin{array}{l}m . e q . \\
63.6 \\
40.1 \\
58.6\end{array}$ & $\begin{array}{l}m . e q . \\
31.0 \\
12.8 \\
42.2\end{array}$ & 7.38 & $\begin{array}{c}\text { mgm. } \\
\text { per } \\
100 \mathrm{cc} . \\
32\end{array}$ & $\begin{array}{c}\text { mgm. } \\
\text { per } \\
100 \mathrm{cc} . \\
88\end{array}$ & $\begin{array}{c}\text { mgm. } \\
\text { per } \\
100 \mathrm{cc} . \\
6.65\end{array}$ & $\begin{array}{c}\underset{\text { mem. }}{\text { per }} \\
100 \mathrm{cc} . \\
8.55\end{array}$ & $\begin{array}{c}\text { m.eq. } \\
\text { per } \\
\text { liter } \\
100.5\end{array}$ & $\begin{array}{c}\text { m.eq. } \\
\text { per } \\
\text { liter } \\
144.1\end{array}$ & $\begin{array}{c}\text { m.eq. } \\
\text { per } \\
\text { liter } \\
3.8\end{array}$ & $\begin{array}{l}\text { m.eq. } \\
\text { per } \\
\text { liter } \\
27.5\end{array}$ & $\begin{array}{c}\text { grams } \\
\text { per } \\
100 \mathrm{cc} . \\
6.57\end{array}$ \\
\hline $\begin{array}{r}\text { Alcohol } 4 \\
5 \\
6\end{array}$ & 70.5 & $\begin{array}{r}800 \\
160 \\
50\end{array}$ & $\begin{array}{l}38.3 \\
24.8 \\
10.1\end{array}$ & $\begin{array}{r}43.0 \\
21.4 \\
4.9\end{array}$ & $\begin{array}{l}9.1 \\
3.3 \\
4.6\end{array}$ & $\begin{array}{l}7.34 \\
7.34\end{array}$ & $\begin{array}{l}31 \\
31\end{array}$ & $\begin{array}{l}91 \\
86\end{array}$ & $\begin{array}{l}13.23 \\
12.88\end{array}$ & $\begin{array}{l}147.0 \\
121.4\end{array}$ & $\begin{array}{l}100.1 \\
104.0\end{array}$ & $\begin{array}{l}144.1 \\
145.3\end{array}$ & $\begin{array}{l}3.5 \\
5.5\end{array}$ & $\begin{array}{l}25.5 \\
25.5\end{array}$ & $\begin{array}{l}6.18 \\
6.48\end{array}$ \\
\hline $\begin{array}{l}7 \\
8 \\
9\end{array}$ & 71.9 & $\begin{array}{r}450 \\
1010 \\
1300\end{array}$ & $\begin{array}{l}28.4 \\
65.6 \\
57.8\end{array}$ & $\begin{array}{l}44.1 \\
33.2 \\
72.1\end{array}$ & $\begin{array}{l}42.4 \\
33.4 \\
41.3\end{array}$ & 7.38 & 27 & & 13.59 & 10.26 & 102.0 & 142.5 & 3.4 & 26.7 & 6.14 \\
\hline
\end{tabular}

* The excretion is the total amount of substances in the urine, stool, and withdrawn blood.

† Diet of 2400 calories, $2400 \mathrm{cc}$. of water, and 7 grams of sodium chloride were given daily. $180 \mathrm{cc}$. of 95 per cent alcohol in the form of distilled gin were given in the fourth period. Periods 1,2 , and 3 are average figures for the corresponding periods during the control days. Blood samples were collected at the end of the periods. 
EFFECT OF ALCOHOL ON WATER AND ELECTROI.YTE BALANCE

TABLE II

Effect of alcohol when adequate sodium chloride was given. Experiment $4 \dagger$

\begin{tabular}{|c|c|c|c|c|c|c|c|c|c|c|c|c|c|c|c|}
\hline Period & Weight & $\begin{array}{l}\text { Water } \\
\text { excre- } \\
\text { tion* }\end{array}$ & $\begin{array}{l}\text { Sodium } \\
\text { excre- } \\
\text { tion * }\end{array}$ & $\begin{array}{l}\text { Chlo- } \\
\text { ride } \\
\text { excre- } \\
\text { tion * }\end{array}$ & $\begin{array}{l}\text { Potas- } \\
\text { sium } \\
\text { excre- } \\
\text { tion * }\end{array}$ & $\begin{array}{l}\text { pH of } \\
\text { blood }\end{array}$ & $\begin{array}{c}\text { Blood } \\
\text { non- } \\
\text { protein } \\
\text { nitro- } \\
\text { gen }\end{array}$ & $\begin{array}{l}\text { Blood } \\
\text { sugar }\end{array}$ & $\begin{array}{l}\text { Blood } \\
\text { lactic } \\
\text { acid }\end{array}$ & $\begin{array}{c}\text { Blood } \\
\text { alco- } \\
\text { hol }\end{array}$ & $\begin{array}{c}\text { Plasma } \\
\text { chlo- } \\
\text { ride }\end{array}$ & $\begin{array}{c}\text { Plasma } \\
\text { so- } \\
\text { dium }\end{array}$ & $\begin{array}{l}\text { Plasma } \\
\text { potas- } \\
\text { sium }\end{array}$ & $\begin{array}{c}\text { Plasma } \\
\mathrm{CO}_{2} \\
\text { content }\end{array}$ & $\begin{array}{c}\text { Plasma } \\
\text { pro- } \\
\text { tein }\end{array}$ \\
\hline 8 hours each & kgm. & $c c$. & m.eq. & m.eq. & m.eq. & & $\begin{array}{c}\text { mgm. } \\
\text { per } \\
100 \text { cc. }\end{array}$ & $\begin{array}{c}\text { mgm. } \\
\text { per } \\
100 \text { cc. }\end{array}$ & $\begin{array}{c}\text { mgm. } \\
\text { per } \\
100 \mathrm{cc} .\end{array}$ & $\begin{array}{c}\text { mgm. } \\
\text { per } \\
100 \text { cc. }\end{array}$ & $\begin{array}{c}\text { m.eq. } \\
\text { per } \\
\text { liter }\end{array}$ & $\begin{array}{c}\text { m.eq. } \\
\text { per } \\
\text { liter }\end{array}$ & $\begin{array}{c}\text { m.eq. } \\
\text { per } \\
\text { liter }\end{array}$ & $\begin{array}{c}\text { m.eq. } \\
\text { per } \\
\text { liter }\end{array}$ & $\begin{array}{c}\text { grams } \\
\text { per } \\
100 \text { cc. }\end{array}$ \\
\hline $\begin{array}{r}\text { Control } 1 \\
2 \\
3\end{array}$ & 66.6 & $\begin{array}{r}1680 \\
500 \\
820\end{array}$ & $\begin{array}{l}52.2 \\
27.1 \\
52.9\end{array}$ & $\begin{array}{l}72.3 \\
18.7 \\
58.8\end{array}$ & $\begin{array}{r}37.3 \\
9.9 \\
36.3\end{array}$ & 7.40 & 26 & 94 & 7.92 & 4.2 & 105 & 141.9 & 2.8 & 26.8 & 6.60 \\
\hline $\begin{array}{r}\text { Alcohol } 4 \\
5 \\
6\end{array}$ & 66.2 & $\begin{array}{r}1990 \\
465 \\
645\end{array}$ & $\begin{array}{l}28.6 \\
26.4 \\
40.3\end{array}$ & $\begin{array}{l}38.1 \\
29.5 \\
40.3\end{array}$ & $\begin{array}{r}2.0 \\
15.9 \\
1.4\end{array}$ & $\begin{array}{l}7.37 \\
7.37\end{array}$ & $\begin{array}{l}29 \\
23\end{array}$ & $\begin{array}{l}97 \\
80\end{array}$ & $\begin{array}{l}12.24 \\
12.24\end{array}$ & $\begin{array}{r}196.6 \\
59.8\end{array}$ & $\begin{array}{l}105.3 \\
107.4\end{array}$ & $\begin{array}{l}144.0 \\
146.9\end{array}$ & $\begin{array}{l}4.2 \\
5.0\end{array}$ & $\begin{array}{l}25.4 \\
26.4\end{array}$ & $\begin{array}{l}6.38 \\
6.52\end{array}$ \\
\hline $\begin{array}{l}7 \\
8 \\
9\end{array}$ & 66.6 & $\begin{array}{r}1400 \\
250 \\
1220\end{array}$ & $\begin{array}{l}39.4 \\
31.8 \\
82.8\end{array}$ & $\begin{array}{l}58.6 \\
24.1 \\
94.3\end{array}$ & $\begin{array}{l}26.9 \\
22.1 \\
55.4\end{array}$ & 7.40 & 28 & 92 & 7.56 & 8.5 & 101.8 & 140.2 & 3.0 & & 6.60 \\
\hline $\begin{array}{l}10 \\
11 \\
12\end{array}$ & 66.8 & $\begin{array}{r}1135 \\
740 \\
1210\end{array}$ & $\begin{array}{l}51.3 \\
31.5 \\
62.7\end{array}$ & $\begin{array}{l}57.0 \\
24.4 \\
91.1\end{array}$ & $\begin{array}{l}27.3 \\
10.7 \\
75.3\end{array}$ & 7.40 & 29 & 96 & 8.59 & 8.5 & 98.7 & 142.0 & 3.0 & & 6.55 \\
\hline
\end{tabular}

* The excretion is the total amount of substances in the urine, stool, and withdrawn blood.

† Diet of 2400 calories, 2400 cc. of water, and 7 grams of sodium chloride were given daily. 200 cc. of 95 per cent alcohol diluted with ice and water were given in the fourth period. Periods 1, 2, and 3 are average figures for the corresponding periods during the control days. Blood samples were collected at the end of the periods. In this experiment the recovery phase was prolonged one day.

TABLE III

Effect of alcohol when inadequate sodium chloride was given. Experiment $3 \dagger$

\begin{tabular}{|c|c|c|c|c|c|c|c|c|c|c|c|c|c|c|c|}
\hline Period & Weight & $\begin{array}{l}\text { Water } \\
\text { excre- } \\
\text { tion * }\end{array}$ & $\begin{array}{l}\text { Sodium } \\
\text { excre- } \\
\text { tion * }\end{array}$ & $\begin{array}{l}\text { Chlo- } \\
\text { ride } \\
\text { excre- } \\
\text { tion* }\end{array}$ & $\begin{array}{l}\text { Potas- } \\
\text { sium } \\
\text { excre- } \\
\text { tion * }\end{array}$ & $\underset{\text { blood }}{\mathrm{pH} \text { of }}$ & $\begin{array}{c}\text { Blood } \\
\text { non- } \\
\text { protein } \\
\text { nitro- } \\
\text { gen }\end{array}$ & $\begin{array}{l}\text { Blood } \\
\text { sugar }\end{array}$ & $\begin{array}{l}\text { Blood } \\
\text { lactic } \\
\text { acid }\end{array}$ & $\begin{array}{l}\text { Blood } \\
\text { alco- } \\
\text { hol }\end{array}$ & $\begin{array}{c}\text { Plasma } \\
\text { chlo- } \\
\text { ride }\end{array}$ & $\begin{array}{c}\text { Plasma } \\
\text { so- } \\
\text { dium }\end{array}$ & $\begin{array}{l}\text { Plasma } \\
\text { potas- } \\
\text { sium }\end{array}$ & $\begin{array}{c}\text { Plasma } \\
\mathrm{CO}_{2} \\
\text { content }\end{array}$ & $\begin{array}{c}\text { Plasma } \\
\text { pro- } \\
\text { tein }\end{array}$ \\
\hline 8 hours each & kgm. & $c c$. & m.eq. & m.eq. & m.eq. & & $\begin{array}{c}\text { mgm. } \\
\text { per } \\
100 \mathrm{cc} .\end{array}$ & $\begin{array}{c}\text { mgm. } \\
\text { per } \\
100 \text { cc. }\end{array}$ & $\begin{array}{c}\text { mgm. } \\
\text { per } \\
100 \text { cc. }\end{array}$ & $\begin{array}{c}\text { mgm. } \\
\text { per } \\
100 \text { cc. }\end{array}$ & $\begin{array}{c}\text { m.eq. } \\
\text { per } \\
\text { liter }\end{array}$ & $\begin{array}{c}\text { m.eq. } \\
\text { per } \\
\text { liter }\end{array}$ & $\underset{\substack{\text { per } \\
\text { liter }}}{\operatorname{m.eq.}}$ & $\underset{\substack{\text { per } \\
\text { liter }}}{\text { m.eq. }}$ & $\begin{array}{c}\text { grams } \\
\text { per } \\
100\end{array}$ \\
\hline Control $\begin{array}{r}1 \\
2 \\
3\end{array}$ & 94.2 & $\begin{array}{r}1730 \\
290 \\
880\end{array}$ & $\begin{array}{l}13.8 \\
22.7 \\
23.0\end{array}$ & $\begin{array}{l}24.3 \\
19.8 \\
36.2\end{array}$ & $\begin{array}{r}50.1 \\
8.8 \\
24.1\end{array}$ & 7.38 & 26 & 98 & 9.2 & 35.39 & 103.2 & 142.9 & 3.8 & 27.1 & 6.75 \\
\hline $\begin{array}{r}\text { Alcohol } 4 \\
5 \\
6\end{array}$ & 93.3 & $\begin{array}{r}2450 \\
225 \\
242\end{array}$ & $\begin{array}{r}19.8 \\
16.7 \\
8.7\end{array}$ & $\begin{array}{l}14.1 \\
20.7 \\
18.2\end{array}$ & $\begin{array}{l}16.9 \\
14.5 \\
12.8\end{array}$ & $\begin{array}{l}7.32 \\
7.35\end{array}$ & $\begin{array}{l}23 \\
25\end{array}$ & $\begin{array}{l}138 \\
102\end{array}$ & $\begin{array}{l}12.87 \\
13.59\end{array}$ & $\begin{array}{l}232.5 \\
104.3\end{array}$ & $\begin{array}{l}104.9 \\
103.2\end{array}$ & $\begin{array}{l}143.1 \\
145.6\end{array}$ & $\begin{array}{l}7.9 \\
8.3\end{array}$ & $\begin{array}{l}24.1 \\
24.6\end{array}$ & $\begin{array}{l}7.03 \\
6.94\end{array}$ \\
\hline $\begin{array}{l}7 \\
8 \\
9\end{array}$ & 94.7 & $\begin{array}{r}570 \\
355 \\
1240\end{array}$ & $\begin{array}{l}5.5 \\
6.7 \\
6.2\end{array}$ & $\begin{array}{l}14.8 \\
11.0 \\
15.5\end{array}$ & $\begin{array}{r}29.0 \\
4.1 \\
30.7\end{array}$ & 7.38 & 25 & 105 & 7.92 & 40.3 & 103.2 & 139.0 & 3.5 & 26.5 & 6.57 \\
\hline
\end{tabular}

* The excretion is the total amount of substances in the urine, stool, and withdrawn blood.

t Diet of 2400 calories, 2400 cc. of water, and 1 gram of sodium chloride were given daily. Periods 1,2 , and 3 are average figures for the corresponding periods during the control days. Blood samples were taken at the end of the periods. 212 cc. of 95 per cent alcohol in the form of whiskey were given during period 4 .

alcohol intake, at which time the blood alcohol had fallen considerably. Actually, however, the recovery day does not begin at this time since water, sodium, potassium, and chloride were retained in large amounts for the first period of that day (Period 7, Tables I, II, and III). Nevertheless, the balances for the complete day reveal that the recovery phase was characterized by urinary excretion of potassium, sodium, and chloride; with retention of water. Since more potassium was retained during the period of alcohol consumption the loss of this ion was greater than for the sodium and chloride. The negative balance on the first day of the recovery period was insufficient 
TABLE IV

Balance data on Experiments 3, 4, and 5 *

\begin{tabular}{|c|c|c|c|c|c|c|c|c|c|c|c|c|c|}
\hline \multirow{2}{*}{$\begin{array}{c}\text { Experi- } \\
\text { ment }\end{array}$} & \multirow{2}{*}{ Day } & \multicolumn{4}{|c|}{ Intake } & \multicolumn{4}{|c|}{ Output } & \multicolumn{4}{|c|}{ Balance } \\
\hline & & $\begin{array}{l}\text { Potas- } \\
\text { sium }\end{array}$ & $\begin{array}{c}\text { So- } \\
\text { dium }\end{array}$ & $\begin{array}{l}\text { Chlo- } \\
\text { ride }\end{array}$ & $\begin{array}{c}\text { Nitro- } \\
\text { gen }\end{array}$ & $\begin{array}{l}\text { Potas- } \\
\text { sium }\end{array}$ & $\begin{array}{l}\text { So- } \\
\text { dium }\end{array}$ & $\begin{array}{l}\text { Chlo- } \\
\text { ride }\end{array}$ & $\begin{array}{l}\text { Nitro- } \\
\text { gen }\end{array}$ & $\begin{array}{l}\text { Potas- } \\
\text { sium }\end{array}$ & $\begin{array}{c}\text { So- } \\
\text { dium }\end{array}$ & $\begin{array}{l}\text { Chlo- } \\
\text { ride }\end{array}$ & $\underset{\text { Nen }}{\text { Nitro- }}$ \\
\hline 3 & $\begin{array}{l}1 \\
2 \\
3\end{array}$ & $\begin{array}{c}\text { m.eq. } \\
85 \\
85 \\
85\end{array}$ & $\begin{array}{r}\text { m.eq. } \\
33.8 \\
33.8 \\
33.8\end{array}$ & $\begin{array}{r}m . e q . \\
54.6 \\
54.6 \\
54.6\end{array}$ & $\begin{array}{l}\text { grams } \\
14.65 \\
14.65 \\
14.65\end{array}$ & $\begin{array}{r}\text { m.eq. } \\
83.0 \\
44.2 \\
63.8\end{array}$ & $\begin{array}{r}\text { m.eq. } \\
59.5 \\
45.2 \\
18.4\end{array}$ & $\begin{array}{c}m . e q . \\
80.3 \\
53.0 \\
40.2\end{array}$ & $\begin{array}{l}\text { grams } \\
13.73 \\
13.80 \\
15.28\end{array}$ & $\begin{array}{l}m . e q . \\
+2.0 \\
+40.0 \\
+21.2\end{array}$ & $\begin{array}{c}\text { m.eq. } \\
-25.7 \\
-11.4 \\
+15.4\end{array}$ & $\begin{array}{c}\text { m.eq. } \\
-25.7 \\
+1.6 \\
+14.4\end{array}$ & $\begin{array}{l}\text { grams } \\
+0.92 \\
+0.85 \\
-0.63\end{array}$ \\
\hline 4 & $\begin{array}{l}1 \\
2 \\
3 \\
4\end{array}$ & $\begin{array}{l}85 \\
85 \\
85 \\
85\end{array}$ & $\begin{array}{l}135.7 \\
135.7 \\
135.7 \\
135.7\end{array}$ & $\begin{array}{l}156 \\
156 \\
156 \\
156\end{array}$ & $\begin{array}{l}14.65 \\
14.65 \\
14.65 \\
14.65\end{array}$ & $\begin{array}{r}83.5 \\
19.3 \\
104.4 \\
113.3\end{array}$ & $\begin{array}{r}132.2 \\
95.3 \\
154.0 \\
145.5\end{array}$ & $\begin{array}{l}149.8 \\
107.9 \\
177.0 \\
172.5\end{array}$ & $\begin{array}{l}14.75 \\
12.21 \\
12.65 \\
14.17\end{array}$ & $\begin{array}{l}+1.5 \\
+65.7 \\
-19.4 \\
-28.3\end{array}$ & $\begin{array}{r}+3.5 \\
+40.4 \\
-18.3 \\
-9.8\end{array}$ & $\begin{array}{r}+6.2 \\
+48.1 \\
-21.0 \\
-16.5\end{array}$ & $\begin{array}{l}-0.10 \\
+2.44 \\
+2.00 \\
+2.20\end{array}$ \\
\hline 5 & $\begin{array}{l}1 \\
2 \\
3\end{array}$ & $\begin{array}{l}85 \\
85 \\
85\end{array}$ & $\begin{array}{l}135.7 \\
135.7 \\
135.7 \\
\end{array}$ & $\begin{array}{l}156 \\
156 \\
156\end{array}$ & $\begin{array}{l}14.65 \\
14.65 \\
14.65\end{array}$ & $\begin{array}{r}86.0 \\
17.0 \\
117.1\end{array}$ & $\begin{array}{r}132.7 \\
73.2 \\
151.8\end{array}$ & $\begin{array}{r}162.4 \\
69.3 \\
149.4\end{array}$ & $\begin{array}{l}15.51 \\
11.95 \\
15.24\end{array}$ & $\begin{array}{r}1.0 \\
+68.0 \\
-32.1\end{array}$ & $\begin{array}{r}+3.0 \\
+62.5 \\
-16.1\end{array}$ & $\begin{array}{r}-6.4 \\
+86.7 \\
+6.6\end{array}$ & $\begin{array}{l}-0.86 \\
+2.70 \\
-0.59\end{array}$ \\
\hline
\end{tabular}

* Alcohol was given at the beginning of the second day in each experiment. The output is the total amount of substances in the urine, stools, and withdrawn blood.

to offset the retention that occurred when the subject consumed the alcohol. One experiment (Table II) was prolonged for an additional day, and it was found that the sodium, potassium, and chloride loss approximately equaled the amount of these ions which had been retained during the period of alcohol consumption.

The retention of potassium was reflected in the concentration of this ion in the plasma (Table V). While there was little or no change immediately following alcohol ingestion, there was a marked increase 8 hours later. The sodium and the chloride concentrations in the plasma were not elevated to a great extent, the largest increase noted was in Experiment 4 (Table II), where the sodium increase was $2.9 \mathrm{~m}$. eq. and the chloride increase was $2 \mathrm{~m}$. eq. In the other experiments this change was not as much, but in each case there was at least an increase of $1.2 \mathrm{~m}$. eq.

We were able to confirm the studies made by Himwich and coworkers (3) who found that after the ingestion of alcohol there was an increase in the blood sugar and lactic acid, and a decrease in the carbon dioxide content and the $\mathrm{pH}$. In none of our experiments were the alterations as much as these workers observed.

Nitrogen was retained in every case, but the positive balance is much more apparent in those experiments in which the sodium chloride intake was adequate; in each of these the amount retained was 2 grams or over, whereas it was less than one gram when the sodium chloride intake was low. There was a reduction in the plasma proteins, which we believe was owing to an increase in blood volume (16). An attempt was made to correlate the blood alcohol concentration with the changes in the water balance, but apparently no comparison could be made.

\section{DISCUSSION}

All variables were controlled as far as possible in these experiments, but the activity of the subjects varied from day to day, and there was an increase in the activity during the period in which alcohol was given. It was observed that the respirations were increased in rate and depth after the alcohol was given, so that more water must have been lost through the expired air and by the increased amount of sweating during this period, than during any other period of the experiment. No measurements were made of the water lost in this manner except that it was observed that more weight was lost during the period of drinking than could be accounted for by the water balance observed. Realizing these facts, we do not believe that a quantitative calculation can be made of the water exchange between the intracellular and extracellular phase.

Darrow and Yannet (17) have estimated that the volume of extracellular fluids is approximately 27 per cent of the body weight. The extracellular fluid volume, however, may not remain 
stationary when conditions of the experiment are altered. In fact, it would appear that in the experiments reported here, there was an increase in the extracellular fluid volume. The retention of sodium and chloride without an increase in the plasma concentration and the increase in the blood volume (16) would indicate this increase. If, however, the assumption is made that the volume of extracellular fluid is approximately equivalent to 27 per cent of the body weight, then only approximately one-half of the retained potassium can be accounted for in this compartment (Table $\mathrm{V})$. As pointed out above, this assumption is

TABLE $\mathbf{V}$

A comparison of the potassium gain in the extracellular fluids with the gain in intracellular potassium

\begin{tabular}{|c|c|c|c|c|c|}
\hline $\begin{array}{c}\text { Ex- } \\
\text { peri- } \\
\text { ment }\end{array}$ & $\begin{array}{c}\text { Retained } \\
\text { potageium } \\
\text { during } 24 \\
\text { hours after } \\
\text { aloohol }\end{array}$ & $\begin{array}{c}\text { Inorease in } \\
\text { plasms } \\
\text { potagsium } \\
\text { concentra- } \\
\text { tion for } \\
\text { same } \\
\text { perlod }\end{array}$ & $\begin{array}{l}\text { Total increase } \\
\text { of potassium in } \\
\text { extracellular } \\
\text { fluid, assuming } \\
\text { them to be } \\
27 \text { per cent } \\
\text { of body weight }\end{array}$ & $\begin{array}{c}\text { Gain of } \\
\text { intracellular } \\
\text { potassium }\end{array}$ & $\begin{array}{c}\begin{array}{c}\text { Intra- } \\
\text { cellular } \\
\text { fluid } \\
\mathrm{K}-0.017 \mathrm{Na}\end{array} \\
0.112\end{array}$ \\
\hline 1 & $\begin{array}{l}\text { m.eq. } \\
50.3\end{array}$ & $\begin{array}{c}\text { m.eg. per liter } \\
1.1\end{array}$ & $\begin{array}{c}\text { m.eq. } \\
19.1\end{array}$ & $\begin{array}{l}\text { m.eq. } \\
31.2\end{array}$ & $\begin{array}{c}\boldsymbol{c c} . \\
275\end{array}$ \\
\hline 2 & 56.8 & 1.9 & 37.4 & 19.4 & 171 \\
\hline 3 & $\mathbf{4 0 . 0}$ & 4.5 & 112.5 & 72.5 & -660 \\
\hline 4 & 65.7 & 2.2 & 39.3 & 26.4 & 220 \\
\hline 5 & 68.0 & 1.7 & 31.6 & 36.4 & 326 \\
\hline
\end{tabular}

probably not correct in these experiments; however, we do not believe that the increase in the extracellular fluid volume was sufficient to account for all of the retained potassium. This excess potassium must be retained in the cells. As pointed out above there was a retention of nitrogen in all of the experiments with the exception of Experiment 3. Experiment 3 was of considerable interest in that the amount of retained potassium was not sufficient to account for the total increase of this ion in the extracellular fluids (Table V). However, this subject was somewhat overweight and his weight was not constant at the beginning of the experiment. $\mathrm{He}$ was also in negative sodium and chloride balance. Peters and Lavietes (18) have pointed out that the relation of body water to tissue solids does not remain constant during periods of changing nutrition. It would appear then that in this subject there was a loss of potassium from the cells by actual destruction, since the gain in extracellular potassium was greater than was expected from the amount retained by the body. It is to be assumed, then, that since both potassium and nitrogen were retained in excess of the amount that was accounted for by the extracellular fluids, there was a gain in the intracellular fluids. If the amount of retained potassium over that accounted for by the increase in the interstitial fluids is used as a basis for calculating the amount of retained intracellular water (19) then it is found that a slight increase in this compartment occurred in all experiments except Experiment 3 (Table V). Again, if the balance of intracellular water is calculated from the amount of retained nitrogen, as suggested by Darrow and Yannet (17), it is found that there is a discrepancy of approximately $100 \mathrm{cc}$. of fluid.

If the retained sodium and chloride be calculated on the same basis, namely, assuming the extracellular fluids to be 27 per cent, it is found that only a very small amount cannot be accounted for in this partition. It should be pointed out that potassium was retained in greater quantity than either the sodium or the chloride ions.

It has been shown that when alcohol is given to dogs a diuresis occurs (1), and we have shown that in man a diuresis occurs in the first part of the drinking period, but that thereafter there is a retention of fluids. It is to be noted that the concentration of sodium, chloride, potassium, and nitrogen in the urine was very much lowered so that the excess urine represents a water diuresis. It would appear therefore that alcohol has an effect on the renal epithelium allowing the water to pass but holding back potassium in large amounts and sodium, chloride, and nitrogen in smaller amounts. When the potassium and nitrogen are considered it appears that the effect of alcohol is not unlike that noted for the absence of the adrenal cortical hormone (20).

During the recovery phase, potassium, sodium, chloride, and nitrogen were lost in greater amounts than they were taken in. Since the loss occurred when the concentration of alcohol in the blood had fallen to lower levels it would appear that the barrier to the excretion of these substances had been removed. The excess of these ions was lost from the extracellular fluid, and if it is assumed that a portion of the intracellular potassium exists in a diffusible form, there would be 
a loss of potassium from the cells. At the same time water was also lost.

It is most unlikely that the shift of water to the intracellular phase is responsible for any of the symptoms resulting from acute alcoholism in man, since the amount of water gained by the cells was too small to bring about edema of any organ. In fact, the most severe symptoms that were noted occurred in Experiment 3, in which the calculated intracellular water was less during the recovery phase than in the beginning of the experiment; however, the plasma potassium concentration had increased to 8.3 m.eq. per liter.

Potassium in excessive amounts is a depressant (21) and produces malaise, nausea, vomiting, and headache, all of which symptoms are observed after excessive alcohol ingestion. It is suggested that the increase in the concentration of plasma potassium after the ingestion of alcohol may be responsible for some of the after effects of overindulgence in alcohol. In our experiments, the unpleasant symptoms of postalcoholic excess appeared at a time when the concentration of alcohol in the blood had fallen and when the potassium concentration was at its maximum.

In all of the experiments reported here there was a slight increase in the level of the blood lactic acid; however, it seems unlikely that the slight increase noted would in any way be responsible for the acidosis produced or for any of the symptoms observed after overindulgence in alcohol.

\section{SUMMARY}

1. Some of the effects of alcohol have been studied by means of balance experiments on healthy adult volunteers in which a constant food, fluid, and salt intake were given. Data from such studies reveal a marked retention of potassium, sodium, chloride, nitrogen, and water.

2 . It is suggested that the retention was produced by the direct action of alcohol on the excretory powers of the kidneys.

3. An increase in the plasma potassium concentration occurred. Reasons are advanced for the belief that some of the symptoms observed following acute alcoholism in man are owing to an increase in the plasma potassium concentration.

4. Previous work on the acid-base balance has been confirmed.

\section{BIBLIOGRAPHY}

1. MacNider, Wm. deB., and Donnelly, G. L., Effect of the prolonged use of ethyl alcohol on renal function and pathology in the dog. Proc. Soc. Exper. Biol. and Med., 1931, 29, 581.

2. Thomas I., Ueber die Wirkung einiger narkotischer Stoffe auf die Blutgase, die Blutalkalescenz und die rothen Blutkörperchen. Arch. f. exper. Path. u. Pharmakol., 1898, 41, 1.

3. Himwich, H. E., Nahum, L. H., Rakieten, N., Fazikas, J. F., DuBois, D., and Gildea, E. F., The metabolism of alcohol. J. A. M. A., 1933, 100, 651.

4. Futer, D. S., Weiland, W. J., and Tarnopolskaja, M. E., Zur Biochemie der Alkoholvergiftung mit Kleinen Dosen. (Experimentelle Untersuchung). Acta med. Scandinav., 1933, 79, 557.

5. Gojcher, B. F., Weiland, W., and Tarnopolskaja, M. E., Zur Frage der biochemischen Veränderungen bei chronischen Alkoholismus. Der Kohlehydratumsatz, die Alkalireserve, die Elektrolyten des Blutes. Acta med. Scandinav., 1933, 79, 563.

6. Wakai, H., Changes in the blood or serum viscosity of the rabbit under the influence of alcohol. Folia Pharmacol. Japon, 1935, 21, 51 and 207.

7. Levin, E., La accion del alcohol sobre el volumen de la sangré circulante. Rec. Soc. argent. de biol., 1935, 11, 277.

8. Harrop, G. A., Soffer, L. J., Ellsworth, R., and Trescher, J. H., Studies on the suprarenal cortex. III. Plasma electrolytes and electrolyte excretion during suprarenal insufficiency in the dog. J. Exper. Med., 1933, 58, 17.

9. Butler, A. M., and Tuthill, E., An application of the uranyl zinc acetate method for determination of sodium in biological material. J. Biol. Chem., 1931, 93, 171.

10. Kerr, S. E., Studies on the inorganic composition of blood. I. The effect of hemorrhage on the inorganic composition of serum and corpuscles. J. Biol. Chem., 1926, 67, 689.

11. Shohl, A. T., and Bennett, H. B., A micro method for the determination of potassium as iodoplatinate. J. Biol. Chem., 1928, 78, 643.

12. Strauss, M. B., The use of thorium nitrate in the rapid ashing of serum and urine. I. Adapted for subsequent potassium determinations. J. Biol. Chem., 1937, 118, 331.

13. Peters, J. P., and Van Slyke, D. D., Quantitative Clinical Chemistry. Vol. II. Methods. Williams and Wilkins Co., Baltimore, 1932.

14. Hastings, A. B., and Sendroy, J., Jr., Studies of acidosis. XX. The colorimetric determination of blood $\mathrm{pH}$ at body temperature without buffer standards. J. Biol. Chem., 1924, 61, 695.

15. Friedemann, T. E., and Klaas, R., The determination of ethyl alcohol. J. Biol. Chem., 1936, 115, 47.

16. Nicholson, W. M., and Taylor, H. M., The blood volume in acute alcoholism. (To be published.) 
17. Darrow, D. C., and Yannet, H., Metabolic studies of the changes in body electrolyte and distribution of body water induced experimentally by deficit of extracellular electrolyte. J. Clin. Invest., 1936, 15, 419.

18. Peters, J. P., and Lavietes, P. H., The nature of "Preformed water." J. Clin. Invest., 1933, 12, 695.

19. Gamble, J. L., Ross, G. S., and Tisdall, F. F., The metabolism of fixed base during fasting. J. Biol. Chem., 1923, 57, 633.

20. Harrop, G. A., Nicholson, W. M., and Strauss, M., Studies on the suprarenal cortex. V. The influence of cortical hormone upon excretion of water and electrolytes in the suprarenalectomized dog. J. Exper. Med., 1936, 64, 233.

21. Sollmann, T., A Manual of Pharmacology. W. B. Saunders Co., Philadelphia, 1936, 5th ed. 